\title{
The effect of in utero protein malnutrition and subsequent renutrition on rat saliva and some salivary enzymes
}

\author{
BY R. R. WATSON \\ Department of Microbiology, Indiana University School of Medicine, \\ 1100 West Michigan Street, Indianapolis, Indiana 46202 USA
}

\section{(Received 13 September 1976 - Accepted 3 December 1976)}

1. Rat pups developed chronic protein insufficiency resulting from malnutrition diet in utero while their dams received $40 \mathrm{~g}$ protein $/ \mathrm{kg}$ diet.

2. Before weaning they were found to have decreased salivary amylase $(E C$ 3.2.1.1) and aminopeptidase activities.

3. A complete diet $(250 \mathrm{~g}$ protein $/ \mathrm{kg})$ rapidly restored salivary amylase activity before weight normalization. However, renourished pups (malnourished pups given $250 \mathrm{~g}$ protein $/ \mathrm{kg}$ for $14 \mathrm{~d}$ ) still had increased numbers of Streptococcus mutans in their plaque.

In secretions from marginally and severely malnourished humans the levels of some proteins such as lysozyme and secretory immunoglobulin A (S-IgA) are significantly decreased, while others such as aminopeptidase $(E C$ 3.4.1.1) and immunoglobulin $\mathrm{G}$ (IgG) are unaffected (McMurray, Rey, Cassazza \& Watson, 1976). Menaker \& Navia (1973b) found that marginally-malnourished young rats had a significantly decreased saliva volume and total salivary protein content, and an increased amount of oral disease as measured by the incidence of caries. The principal salivary protein, $\alpha$-amylase $(\alpha-1,4$-glucan 4 -glucanhydrolase; $E C$ 3.2.1.1) functions in the degradation of starches in the oral cavity and therefore is important in both the nutritional environment of the mouth and the conversion of dietary carbohydrates in adsorbable sugars.

The present experiments were done to study the activity of salivary enzymes such as amylase, from rat pups malnourished in utero, and to determine the effects of a nutritional restoration.

\section{MATERIALS AND METHODS \\ In utero malnutrition of rats}

Rat dams (COD-OD; Charles River Breeding Laboratories, Wilmington, Mass., USA) were randomly divided into two groups. They received an excess of an isoenergetic, agargel diet containing 40 or $25 \mathrm{~g}$ protein $/ \mathrm{kg}$, beginning $7 \mathrm{~d}$ before conception. The diet was prepared as described by Menaker \& Navia (1973a). The $40 \mathrm{~g}$ protein $/ \mathrm{kg}$ diet differed from the normal $(250 \mathrm{~g}$ protein $/ \mathrm{kg}$ ) diet only in the amount of protein; $210 \mathrm{~g}$ protein $/ \mathrm{kg}$ dry diet was replaced by an equal weight of starch (Table 1). Water and diet were available at all times. The animals were maintained at $22 \pm 2^{\circ}$ and $65 \pm 5 \%$ relative humidity. The daily illumination cycle consisted of alternating $12 \mathrm{~h}$ periods of light or dark. All animals born to each mother were included in the experiment. At day 21 all pups were weaned and then fed ad lib. the same diet as their mothers. Some of the young rats which had been malnourished in utero by giving the $40 \mathrm{~g}$ protein $/ \mathrm{kg}$ diet to their dams were renourished by giving the $250 \mathrm{~g}$ protein $/ \mathrm{kg}$ diet at weaning. 
Table 1. Composition ( $\mathrm{g} / \mathrm{kg}$ dry ingredients) of agar gel casein diet fed to rats

$\begin{array}{lrr}\text { Protein content }(\mathrm{g} / \mathrm{kg}) & 40 & 250 \\ \quad \text { Ingredient } & & \\ \text { Casein } & 3.71 & 24 \cdot 72 \\ \text { DL-methionine } & 0.30 & 0.30 \\ \text { Dextrose glucose } & 16.68 & 16.68 \\ \text { Sucrose } & 16.77 & 16.72 \\ \text { Dextrin } & 16.68 & 16.68 \\ \text { Maize starch } & 20.98 & 0.97 \\ \text { Maize oil } & 15.02 & 15.02 \\ \text { Salt mix } & 4.00 & 4.00 \\ \text { Vitamin mix } \dagger & 1.00 & 1.00 \\ \text { Choline } \ddagger \text { (ml) } & 0.40 & 0.40 \\ \text { Agar } & 3.59 & 3.59 \\ \text { Distilled water }(\mathrm{ml}) & 1000 & 1000\end{array}$

* Nutritional Biochemicals, Cleveland, Ohio.

$\dagger$ The ergocalaferd phylloquinone vitamin mixture contained (mg): retinyl acetate and $D_{2}, 1.000$; Itoeophenyl acetate $(250 \mathrm{mg} / \mathrm{g}), 40.000 ; \mathrm{K}, 0.500$; thiamin hydrochloride, 1.000 ; riboflavin, 2.000 ; nicotinic acid 5.000; carboacide, 20.000; pyridoxine, 1.000; $p$-aminobenzoic acid, 10.000; biotin, 0.0500; calcium pantothenate, 5.000 ; acid, 0.200; myo-inositol, 20.000 ; cyanocobalamin $1 \mathrm{mg} / \mathrm{g}, 5000$ and sucrose, 890.270 .

$\ddagger$ Choline prepared by adding $50 \mathrm{~g}$ choline chloride to $50 \mathrm{ml}$ distilled water.

$\S$ Dry ingredients added to $1000 \mathrm{ml}$ distilled water.

\section{Plaque}

Colonization by streptococci of the oral cavity in rats was estimated by counting viable streptococci and Streptococcus mutans isolated from dental plaque as described by Bowen (1969). After killing the rats, the plaque was scraped from the surfaces of all molars with a sterile explorer, placed in $2.0 \mathrm{ml}$ sterile, yeast extract $(0.5 \mathrm{~g} / \mathrm{l})$ and cultured for determination of total streptococci and $S$. mutans counts in an atmosphere of hydrogen and carbon dioxide.

\section{Collection of saliva}

Nembutal collection of saliva was used to anaesthetize the rats by giving $20.0 \mathrm{mg} / \mathrm{kg}$ body-weight intraperitoneally (Abbott Laboratories, North Chicago, III. USA). At the same time as the Nembutal, a freshly prepared solution of pilocarpine (Sigma Chemical Co., St Louis Mo., USA) $3 \mathrm{mg} / \mathrm{ml}$ was administered intraperitoneally, with a dose of $6.0 \mathrm{mg} / \mathrm{kg}$ body-weight. Before saliva collection, the mouth of each rat was cleaned with water and dried with a cotton-tipped applicator. Saliva was quantitatively collected from the mouth using Pasteur pipettes. Contamination from lachrymal and nasal secretions was reported to be avoided by this technique (Menaker \& Navia, 1973 b), and losses because of swallowing or dripping were minimal. A standard collection period of $30 \mathrm{~min}$ was used after pilocarpine injection. The saliva was placed in sterile, preweighed, polystyrene test-tubes $(12 \times 75 \mathrm{~mm})$ cooled in an ice-bucket. It was collected on ice and centrifuged at $8000 \mathrm{~g}$ for $10 \mathrm{~min}$. The precipitate was discarded and the samples were frozen at $-20^{\circ}$ after assay for amylase activity. One sample only was collected from each rat.

\section{Enzyme assays}

Amylase activity was measured on portions of the centrifuged saliva immediately after collection using micro modification of the procedure of Dahlqvist (1962). The saliva sample was diluted $1: 300(\mathrm{v} / \mathrm{v})$ with $0.02 \mathrm{M}$-potassium phosphate buffer, $\mathrm{pH} 6.9$, and $0.2 \mathrm{ml}$ was added to $0.2 \mathrm{ml}$ soluble starch solution $(1 \mathrm{~g} / \mathrm{l})$ containing $0.4 \mathrm{~g}$ sodium chloride/l. After 
incubation at $30^{\circ}$ for $3 \mathrm{~min}$, the reaction was terminated by adding $0.4 \mathrm{ml} \mathrm{3,5-dinitro-}$ salicylate reagent (containing $(/ 1): 10 \mathrm{~g} \mathrm{3,5-dinitrosalicylic} \mathrm{acid,} 16 \mathrm{~g}$ sodium hydroxide, $300 \mathrm{~g}$ sodium potassium tartrate). The reaction mixture was boiled vigorously in a waterbath for $5 \mathrm{~min}$ and cooled immediately to $22^{\circ}$. Distilled water was added and extinction at $540 \mathrm{~nm}$ was measured using a spectrophotometer (Beckman Model 24; Beckman Instruments Co., Fullerton, Calif.).

Aminopeptidase activity was assayed using the procedure described by Watson (1976), using two substrates (Mann Research Laboratories, Division of Becton, Dickinson Co., New York, N.Y., USA), L-alanyl- $\beta$-naphthylamide (ala- $\beta$ NA) and L-methionyl- $\beta$-naphthylamide (met- $\beta$ NA). Portions of centrifuged saliva were diluted to $1 \times 10^{-3} \mathrm{M}$ and $9 \times 10^{-4} \mathrm{M}$ for assays using ala- $\beta \mathrm{NA}$ and met- $\beta \mathrm{NA}$, respectively, in $0.1 \mathrm{M}-\mathrm{Tris}-\mathrm{HCl}, \mathrm{pH} 8.0$ and stored at $4^{\circ}$ until used. The extent of hydrolysis for the $\mathrm{N}$-terminal methionine or alanine from a protein or peptide was measured with the synthetic $\beta$-naphthylamides (Watson, 1976). Saliva was thawed and $0.010 \mathrm{ml}$ was added to $0.400 \mathrm{ml}$ substrate and incubated for $3 \mathrm{~h}$ at $37^{\circ}$. The fluorescence of any $\beta$-naphthylamine (Mann Research Laboratories, Division of Becton, Dickinson Co., New York, N.Y., USA) released was measured using an Aminco fluorometer with a Corning 7-37 primary filter and a Wratten 47B secondary filter. Any increase in fluorescence compared with the value for the control (substrate without addition of secretion) was measured and compared to the fluorescence of a totally hydrolysed standard, $1 \times 10^{-4} \mathrm{M}-\beta$-naphthylamine. One unit of aminopeptidase activity was defined as the release of $1 \mathrm{nmol} \beta$-napthylamine from a $1 \times 10^{-3} \mathrm{M}$-ala- $\beta \mathrm{NA}$ or met- $\beta \mathrm{NA}$ solution $/ \mathrm{h}$ at $37^{\circ}$. Total protein content was determined by the method of Lowry, Rosebrough, Farr $\&$ Randall (1951). These concentrations were found to be 5-6 times the apparent $\mathrm{K}_{\mathrm{m}}$ concentration of each amino acyl $\beta$ NA using rat salivary aminopeptidase. It was the maximum amount which could be put into solution.

\section{RESULTS}

Fewer pups were born to dams given the $40 \mathrm{~g}$ protein $/ \mathrm{kg}$ diet with $8.3 \mathrm{pups} /$ litter compared to 13.0 pups/litter from the normal dams. The malnourished pups weighed significantly less than the normal pups at day $12,9.7 \pm 1.8 \mathrm{~g}$, and $26.8 \pm 3.0 \mathrm{~g}$ respectively. At weaning the female rat pups weighed $26 \cdot 7 \pm 5 \cdot 2 \mathrm{~g}$ while the normal pups weighed $48 \cdot 2 \pm$ $3.1 \mathrm{~g}$ which was significantly $(P<0.01)$ heavier. After weaning, the malnourished pups continued to gain significantly less weight than the normal pups. The malnourished pups consumed $22 \pm 4 \%$ less diet by weight than controls measured at several different times. The malnourished pups had lower serum albumin contents than the normal pups at day 12 with $1 \cdot 70 \pm 0 \cdot 10 \mathrm{~g} / \mathrm{l}$ compared to $2 \cdot 48 \pm 0 \cdot 17 \mathrm{~g} / \mathrm{l}$.

There were significant differences in values for the volume of saliva or total salivary protein collected during $30 \mathrm{~min}$ of stimulation of the salivary glands by pilocarpine between the normal and the severely-malnourished rats (Table 2). At days 12, 21 and 56 the spleen, thymus and parotid glands of the malnourished female rats were significantly smaller. At day 12 the parotid glands weighed $0.018 \pm 0.006 \mathrm{~g}$ and $0.055 \pm 0.003 \mathrm{~g}$ for the malnourished and normal pups, respectively. At weaning the parotid glands from the malnourished pups weighed $0.023 \pm 0.008 \mathrm{~g}$, while those of the normal pups were heavier, $0.058 \pm 0.006 \mathrm{~g}(P<0.05)$. Malnourished rat pups of dams given $40 \mathrm{~g}$ protein $/ \mathrm{kg}$ diet from conception showed a significant decrease in amylase activity $(/ \mathrm{ml})$ by weaning, day 21 (Table 2). The total amylase activity in saliva samples collected in 30 min was significantly lower $(P<0.02)$ in the malnourished pups at day 56 . The specific activity was half that at day 21 and more than $80 \%$ lower at day 56 . Pups which were renourished for $14 \mathrm{~d}$ after weaning had values for salivary amylase activity which were similar to those for normal pups controls (Table 3). 
Table 2. Saliva flow rate and protein secretion in female rat pups malnourished in utero*

\begin{tabular}{|c|c|c|c|c|c|c|c|c|c|}
\hline \multicolumn{2}{|l|}{ Period after birth (d) } & \multicolumn{2}{|c|}{14} & \multicolumn{2}{|c|}{21} & \multicolumn{2}{|c|}{56} & \multicolumn{2}{|c|}{$\begin{array}{c}35+ \\
\text { (Renourished) }\end{array}$} \\
\hline & $\begin{array}{l}\text { Feeding } \\
\text { regimen }\end{array}$ & Mean & SE & Mean & SE & Mean & SE & Mean & SE \\
\hline imulated saliva $\uparrow$ & $\begin{array}{l}\text { Normal } \\
\text { Malnourished }\end{array}$ & $\begin{array}{l}0.570 \\
0.520\end{array}$ & $\begin{array}{l}0.05 \\
0.05\end{array}$ & $\begin{array}{l}0.210 \\
0.270\end{array}$ & $\begin{array}{l}0.05 \\
0.06\end{array}$ & $\begin{array}{l}0.385 \\
0.309\end{array}$ & $\begin{array}{l}0.04 \\
0.06\end{array}$ & $\begin{array}{l}0.820 \\
0.680\end{array}$ & $\begin{array}{c}0.23 \\
0.12\end{array}$ \\
\hline otein secretion & $\begin{array}{l}\text { Normal } \\
\text { Malnourished }\end{array}$ & $\begin{array}{l}27 \cdot 7 \\
18 \cdot 6\end{array}$ & $\begin{array}{l}1.6 \\
1.4\end{array}$ & $\begin{array}{l}10 \cdot 9 \\
12.9\end{array}$ & $\begin{array}{l}1 \cdot 2 \\
2.5\end{array}$ & $\begin{array}{l}18 \cdot 8 \\
18 \cdot 4\end{array}$ & $\begin{array}{l}2 \cdot 7 \\
3 \cdot 3\end{array}$ & $\begin{array}{l}39 \cdot 1 \\
29 \cdot 6\end{array}$ & $\begin{array}{l}1 \cdot 0 \\
5 \cdot 3\end{array}$ \\
\hline
\end{tabular}

* Dams were malnourished, beginning at conception, by giving a diet containing $40 \mathrm{~g}$ protein $/ \mathrm{kg}$ until weaning pups at day 21 ; normal dams were given a diet containing $250 \mathrm{~g}$ protein $/ \mathrm{kg}$. For details of feeding regimens, see p. 233. At weaning malnourished pups were given a diet containing $250 \mathrm{~g}$ protein $/ \mathrm{kg}$ for $14 \mathrm{~d}$.

$\uparrow$ Pilocarpine-stimulated saliva secretion with Nembutal anaesthetization.

$\ddagger$ Values for normal pups significantly different from those for malnourished pups $(P<0.05)$.

Table 3. Amylase (EC 3.2.1.1) and aminopeptidase activity in saliva from female rat pups malnourished in utero $\dagger$

\begin{tabular}{|c|c|c|c|c|c|c|c|c|c|}
\hline \multirow[t]{2}{*}{ Period after birth (d) } & \multirow{2}{*}{$\begin{array}{l}\ldots \\
\text { Feeding } \\
\text { regimen }\end{array}$} & \multicolumn{2}{|c|}{14} & \multicolumn{2}{|c|}{21} & \multicolumn{2}{|l|}{56} & \multicolumn{2}{|c|}{$\begin{array}{c}35 \| \\
\text { (Renourished) }\end{array}$} \\
\hline & & Mean & SE & Mean & SE & Mean & SE & Mean & SE \\
\hline $\begin{array}{l}\text { Amylase } \\
\text { units } \neq / \mathrm{ml}\end{array}$ & $\begin{array}{l}\text { Normal } \\
\text { Malnourished }\end{array}$ & $\begin{array}{l}816 \\
600\end{array}$ & $\begin{array}{l}221 \\
223\end{array}$ & $\begin{array}{r}1306 \\
596\end{array}$ & $\begin{array}{l}192 \\
123^{*}\end{array}$ & $\begin{array}{r}1340 \\
358\end{array}$ & $\begin{array}{l}73 \\
85^{*}\end{array}$ & $\begin{array}{l}924 \\
851\end{array}$ & $\begin{array}{r}285 \\
97\end{array}$ \\
\hline Units $\ddagger / 30$ mins $\S$ & $\begin{array}{l}\text { Normal } \\
\text { Malnourished }\end{array}$ & $\begin{array}{l}463 \\
311\end{array}$ & $\begin{array}{l}125 \\
116\end{array}$ & $\begin{array}{l}278 \\
158\end{array}$ & $\begin{array}{l}41 \\
33\end{array}$ & $\begin{array}{l}623 \\
111\end{array}$ & $\begin{array}{l}34 \\
26^{*}\end{array}$ & $\begin{array}{l}754 \\
580\end{array}$ & $\begin{array}{r}232 \\
66\end{array}$ \\
\hline $\begin{array}{l}\text { Units } \ddagger / \mathrm{mg} \text { protein } \\
\text { Aminopeptidase: }\end{array}$ & $\begin{array}{l}\text { Normal } \\
\text { Malnourished }\end{array}$ & $\begin{array}{l}18 \cdot 8 \\
16 \cdot 7\end{array}$ & $\begin{array}{l}5 \\
6\end{array}$ & $\begin{array}{l}25 \cdot 5 \\
12 \cdot 2\end{array}$ & $\begin{array}{l}4 \\
3\end{array}$ & $\begin{array}{r}33 \cdot 1 \\
6 \cdot 0\end{array}$ & $\begin{array}{l}2 \\
1\end{array}$ & $\begin{array}{l}23 \cdot 7 \\
19 \cdot 6\end{array}$ & $\begin{array}{l}7 \\
2\end{array}$ \\
\hline Units $\rrbracket / m l$ & $\begin{array}{l}\text { Normal } \\
\text { Malnourished }\end{array}$ & $\begin{array}{l}29 \cdot 7 \\
14 \cdot 2\end{array}$ & $\begin{array}{r}10 \cdot 2 \\
3 \cdot 0\end{array}$ & $\begin{array}{l}76 \cdot 7 \\
27 \cdot 5\end{array}$ & $\begin{array}{l}1 \cdot 2 \\
2 \cdot 5^{*}\end{array}$ & $\begin{array}{l}94 \cdot 1 \\
27 \cdot 5\end{array}$ & $\begin{array}{l}2 \cdot 7 \\
4 \cdot 1 *\end{array}$ & $\begin{array}{l}89 \cdot 9 \\
65 \cdot 8\end{array}$ & $\begin{array}{r}12 \cdot 5 \\
5 \cdot 7\end{array}$ \\
\hline Units $\Psi / 30 \mathrm{~min} \S$ & $\begin{array}{l}\text { Normal } \\
\text { Malnourished }\end{array}$ & $\begin{array}{r}16 \cdot 9 \\
7 \cdot 3\end{array}$ & $\begin{array}{l}5 \cdot 0 \\
2 \cdot 0\end{array}$ & $\begin{array}{r}16 \cdot 3 \\
7.2\end{array}$ & $\begin{array}{l}2 \cdot 1 \\
0.6^{*}\end{array}$ & $\begin{array}{l}43 \cdot 8 \\
10 \cdot 4\end{array}$ & $\begin{array}{l}2.5 \\
0.6^{*}\end{array}$ & $\begin{array}{l}61.0 \\
53.6\end{array}$ & $\begin{array}{l}16 \cdot 0 \\
11 \cdot 7\end{array}$ \\
\hline $\begin{array}{l}\text { Units } / / \mathrm{mg} \\
\text { protein }\end{array}$ & $\begin{array}{l}\text { Normal } \\
\text { Malnourished }\end{array}$ & $\begin{array}{l}0.65 \\
0.40\end{array}$ & $\begin{array}{l}0.4 \\
0.7\end{array}$ & $\begin{array}{l}1.9 \\
0.6\end{array}$ & $\begin{array}{l}0.2 \\
0.6 *\end{array}$ & $\begin{array}{l}2 \cdot 2 \\
0.5\end{array}$ & $\begin{array}{l}0.4 \\
0.6^{*}\end{array}$ & $\begin{array}{l}2 \cdot 1 \\
1 \cdot 4\end{array}$ & $\begin{array}{l}0.1 \\
0.1\end{array}$ \\
\hline
\end{tabular}

* Values for normal pups were significantly different from those for malnourished pups $(P<0.02)$.

$\dagger$ Dams were malnourished, beginning at conception, by giving a diet containing $40 \mathrm{~g}$ protein $/ \mathrm{kg}$ until weaning of pups.

$\ddagger$ One unit of activity was defined as the release of $1 \mathrm{mg}$ maltose at $37^{\circ}$.

$\S$ Activity in saliva collected in $30 \mathrm{~min}$.

II At weaning malnourished pups were given a diet containing $250 \mathrm{~g}$ protein $/ \mathrm{kg}$ for $14 \mathrm{~d}$.

If Nmol methionyl- $\beta$-naphthylamide hydrolysed/h.

Aminopeptidase activity as measured by hydrolysis of met- $\beta$ NA, was present in the saliva of normal rats. The aminopeptidase activity increased significantly from day 14 to day 56 as shown in Table 3. All values for aminopeptidase activity $(/ \mathrm{ml})$, activity in saliva collected in $30 \mathrm{~min}$ and the specific activity, were significantly lower at day 21 and day 56 in the malnourished pups compared to normal pups $(P<0.001)$. However, the pups which had been renourished for $14 \mathrm{~d}$ with the $25 \mathrm{~g}$ protein $/ \mathrm{kg}$ diet had values for aminopeptidase activity which were similar to those of the normal pups (Table 2).

Some of the pups born to dams given the $40 \mathrm{~g}$ protein $/ \mathrm{kg}$ diet were renourished for $28 \mathrm{~d}$ 


\section{Table 4. Streptococci and Streptococcus mutans counts in dental plaque isolated $\ddagger$ from rats malnourished in utero§}

$\begin{array}{lccc} & \begin{array}{c}\text { Total streptococci } \\ \times 10^{3} \text { (no./ml } \\ \text { Flaque solution) }\end{array} & \begin{array}{c}S . \text { mutans } \times 10^{3} \\ \text { (no./ml } \\ \text { plaque solution) }\end{array} & \begin{array}{c}\text { Wt of rats when } \\ \text { killed at day } 49(\mathrm{~g})\end{array} \\ \text { Normal } & 340 \pm 90 & 0.4 \pm 4 \dagger & 405 \pm 10 \dagger \\ \text { Malnourished } & 1150 \pm 120^{*} & 440 \pm 7^{*} & 172 \pm 7 \dagger \\ \text { Malnourished (renourished) } \| & 630 \pm 90^{*} & 180 \pm 20^{*} \dagger & 323 \pm 19 \dagger\end{array}$

* Value significantly higher than that for normal pups $(P<0.001)$.

$\dagger$ Value significantly lower than that for malnourished pups $(P<0.01)$.

\$ Plaque isolated from all teeth immediately on killing and suspended into $2 \mathrm{ml}$ media.

$\S$ Dams were malnourished, beginning at conception, by giving a diet containing $40 \mathrm{~g}$ protein $/ \mathrm{kg}$ until weaning of pups.

II Pups given the diet containing $250 \mathrm{~g} / \mathrm{kg}$ from weaning at day 21 until killed at day 49 .

after weaning by giving the $250 \mathrm{~g}$ protein $/ \mathrm{kg}$ diet. The renourished pups and the normal pups born to dams given the $250 \mathrm{~g}$ protein $/ \mathrm{kg}$ diet had significantly less streptococci than the severely malnourished pups (Table 4 ). There were significantly more $S$. mutants isolated from the plaque of the severely-malnourished rats given the $40 \mathrm{~g}$ protein $/ \mathrm{kg}$ diet and that of the malnourished rats given the $250 \mathrm{~g}$ protein $/ \mathrm{kg}$ diet after weaning, than were isolated from the controls given the $250 \mathrm{~g}$ protein $/ \mathrm{kg}$ diet (Table 4 ).

\section{DISCUSSION}

Severe protein malnutrition initiated at conception caused reduced growth of the pups while nursing. This resulted in reduced levels of salivary amylase and aminopeptidase activity at weaning. The lower activities at day 14 suggested that this trend may have begun earlier than weaning. McGhee and his co-workers (Michalek, McGhee \& Ghanta, 1974) have shown that moderate malnutrition with an $80 \mathrm{~g}$ protein $/ \mathrm{kg}$ diet begun at conception, results in significantly decreased milk volume. The total protein and complement levels are also reduced in the milk supplied by the malnourished dams, resulting in malnourished pups.

In children, malnutrition often results in increased infections of mucosal surfaces (Jose, Shelton, Tauro, Belbin, \& Hosking, 1975; Bell, Turner, Gracey, Suharjono \& Sunoto, 1976). Similar observations have been made in the marginally-malnourished rat by Menaker \& Navia (1973b). They found increased caries in marginally-malnourished pups when given a high-protein, cariogenic diet at weaning. The results of the present work suggested in dental plaque an increase in total streptococci as well as $S$. mutans, the principal oetiological agent associated with caries. Significantly increased numbers of $S$. mutans were found in plaque isolated from renourished rats which were given the same diet as the normal pups. This suggested that nutritional deprivations rather than the high carbohydrate levels of the $40 \mathrm{~g}$ protein $/ \mathrm{kg}$ diet given to the dams were primarily responsible for increased oral disease. There are several explanations for the apparently reduced oral disease resistance. Severe protein malnutrition may cause significant decreases in secretory immunoglobulin levels and antibody responses in rat saliva as seen in secretions of malnourished children (Chandra, 1975). Alternatively the decreased amylase activity in the severely-malnourished pups could have aided the persistence of starch in the oral cavity resulting in increased plaque and $S$. mutans colonization. Because the surface area of the tooth remains relatively constant and similar in malnourished pups compared to normal pups (Diorio, Miller \& Navia 1973), the decrease in amylase activity at weaning could contribute to poor tooth cleansing and increased accumulation of more slowly degraded dietary starch. Poorer tooth develop- 
ment and mineralization was considered by Menaker \& Navia $(1973 b)$ as a possible explanation for the increased caries they observed in rats suffering chronic protein insufficiency. It would not, however, be a feasible explanation for increased $S$. mutans in plaque of renourished rats.

The results of the present study suggested that the effects of in utero malnutrition with a very-low-protein diet were to reduce significantly the activity of the principal salivary amylase, as well as aminopeptidase transudated into secretions from the serum. In humans, levels of proteins produced in mucosal tissues for secretion, in particular secretory IgA and lysozyme, are reduced (McMurray et al. 1976; Reyes, Tye \& Watson, 1976; Watson, Tye, McMurray \& Reyes, 1977). However, lower levels of those proteins, such as IgG, albumin and aminopeptidase, synthesized elsewhere for transudation into the secretions, have not been observed except in some children suffering from severe combined nutritional deficiencies (McMurray, Reyes \& Watson, 1977). Decreased amylase activity in secretions could be understood on the basis that increased tissue catabolism and decreased protein synthesis are the usual consequences of dietary protein deficiency. Changes in enzyme levels during undernutrition often occur against a background of continual synthesis and degradation of protein. It is possible that decreased enzyme activity might be the result of inactivation of existing enzyme protein. Although this explanation seems unlikely for an enzyme such as amylase, which is regularly secreted and lost, it is possible that the almost universally lower levels of amylase in the saliva of severely malnourished rat pups result from abnormal synthesis rates of amylase and, therefore, the secretion of lower amounts of active enzyme.

The author thanks Mrs Cora Foulks and Mrs Joan Roberts for technical assistance, and the National Institutes of Health, Bethesda, Maryland, USA, for grant no. HD-09098 for partial support of this project.

\section{REFERENCES}

Bell, R. G., Turner, K. J., Gracey, M., Suhariono, N. D. \& Sunoto, M. D. (1976). Am. J. clin. Nutr. 29, 392. Bowen, W. H. (1969). Br. dent. J. 126, 159.

Chandra, R. K. (1975). Br. med. J. ii, 583.

Dahlquist, A. (1962). Scand. J. clin. Lab. Invest. 14, 145.

Diorio, L. P., Miller, S. A. \& Navia, J. M. (1973). J. Nutr. 103, 856.

Jose, D. G., Shelton, M., Tauro, G. P., Belbin, R. \& Hosking, C. S. (1975). Med. J. Aust. 2, 699.

Lowry, O. H., Rosebrough, N. J., Farr, A. L. \& Randall, R. J. (1951). J. Biol. Chem. 193, 265.

McMurray, D. N., Rey, H., Casazza, L. J. \& Watson, R. R. (1976). Fedn. Proc. Fedn. Am. Socs. exp. Biol. $35,588$.

McMurray, D. N., Reyes, M. A. \& Watson, R. R. (1977). Fedn. Proc. Fedn. Am. Socs. exp. Biol. 36, 1171.

Menaker, L. \& Navia, J. M. (1973a). J. Dent. Res. 52, 680

Menaker, L. \& Navia, J. M. (1973b). J. Dent. Res. 52, 688.

Michalek, S. M., McGhee, J. R. \& Ghanta, V. K. (1974). J. Reticuloendoth. Soc. 16, 213.

Reyes, M. A., Tye, J. C. \& Watson, R. R. (1976). Fedn. Proc. Fedn. Am. Socs. exp. Biol. 35, 261.

Watson, R. R. (1976). Meth. Microbiol. 9, 1.

Watson, R. R., Tye, J. C., McMurray, D. N. \& Reyes, M. A. (1977). Am. J. clin. Nutr. 30, 599. 